\title{
SPONTANEOUS MORPHOGENETIC JUVENILIZATION OBSERVED IN LABORATORY POPULATIONS OF VECTOR SPECIES OF CHAGAS DISEASE (TRIATOMINAE).
}

\author{
Alina Perlowagora-Szumlewicz * with the technical assistance of Hermenegildo, \\ N. da Cruz ** and Julieta, A. Nabuco de Araújo ***
}

Reported are observations on spontaneous occurring morphogenetic juvenilization in laboratory populations of vector species of Chagas disease. Two general effects have been observed: arrested development and uncoordinated development. These are manifested by supernumerary nymphs (6th stage), intermediate nymphal-adult stages, badly deformed adults developed from 5 th instar nymphs, uncoordinated development manifested by grotesque forms of adults, supernumerary adults unable to complete metamorphosis and complete supernumerary adults produced by 6th stage nymphs.

The reoccurrence of insects with identical grades of juvenilization in the population is an indication that this is a genetic trait that might be inherited. The factors responsible for morphogenetic juvenilization cannot be transmitted through the juvenilized insects because they are sterile, than they were transmitted through normal insects probably as a recessive or a group recessive factors.

The spontaneous morphogenetic juvenilization observed in laboratory populations has a striking similarity to juvenilizing effects induced by application of juvenile hormone analogues, described in the literature and also obtained in our laboratory in a study to be published. Thus it is suggested that both; the altered phenotypes occurring in wild populations and their "phenocopies" induced by the application of juvenile hormone analogues are products of gene controlled identical reactions.

\section{INTRODUCTION}

Data of the study herein described were taken from a longterm project designed to develop marker strains for vector species of Chagas disease, essential for the production of genetic control schemes, and for studies of mechanisms involved in resistance and susceptibility to insecticides.
At present studies on this subject are limited to screening laboratory populations of vector species for aberrant individuals readily distinguished from normal phenotypes, making single-pair matings and studying their viability and offspring for three generations to recover recessives.

Some of these individuals show conspicuous morphological characteristics which

Núcleo Central de Pesquisas do Instituto de Endemias Rurais, FIOCRUz. Thts study has been supported in part by the Conselho Nacional de Pesquisas and by U.S. Army grant DAHC 19-72-0015 (to Dr. B. GILBERT)

- Chief of the Laboratory of Insect Biology and Control, Núcleo Central de Pesquisas. Estrada da Covanca, 56 - Jacarepaguá - GB.

$* *, * \star *$ Laboratory of Insect Blology and Control.

Recelved for publication on 6.15.1973. 
affect mainly the pattern of adult wings and other adult appendages. These "abnormalities" may or may not turn out to be good markers.

In others individuals two general effects have been observed: arrested development and uncoordinated development. These are manifested by production of supernumerary nymphs (6th stage), supernumerary adults (7th stage), grotesque forms of nymphal-adult intermediates and imaginal stages unable to complets metamorphosis

A distinction between the recovered aberrant phenotypes and deformations associated with suppressed or impaired morphogenesis was evident. Neither the general morphology of the latter, nor conclusions regarding their function based upon behavioural analysis allow one to classify the "abnormalities" recovered into one group only. Thus, at least two distinct functional kinds of aberrations are identifiable with the possibility of additional ones being found as research unfolds.

Reported here are the typical types of developmental deformations so far reported for species of various insect orders exposed to compounds related chemically to the cecropia juvenile hormone which was first obtained by Wallians $(17,18)$ and identified by Dahm et al. $(4,5)$. The group of phenotypic variants will form the subject of a separate papel

We know of no previous observations on spontaneous occurring juvenilizing effects in populations of vector species of Chagas disease, nor of any attempts to study this; yet it might be not only of thecretical interest in the field of insect phys!ology but also useful in searching for greater effects and lesser hazards than conventional insecticides for controlling insects

\section{MATERIAL AND METHODS}

Insects utilized in this study were from colonies established in the laboratory since 1969. Populations of the following vector species have been screened: Triatoma infestans (Klug, 1834), Triatoma sordida (Stal, 1859), Triatomx brasi iensis (Neiva, 1911), Triatoma pseudomaculata, (Corrêa e Espinola, 1964), Rhodnius neglectus (Lent,
1954), Rhodnius prolixus (Stal, 1859) and Panstrongylus megistus (Burmeister, 1835).

The geographic position of the states from which the first six vector spec'es originated and their maintenance in the laboratory has been described previously $(9,10)$. The 7 th vector species $P$. megistus originated from Pacayús, State of Ceara.

The procedure adopted in our laboratory of sexing insects in their 5th nymphal stage and keep:ng them in separate vials for emergence of adults proved convenient for the present study. The 6th stage nymphs resulting from extra ecdycis and the intermediate forms were readily distinguished in the vials containing solely 5th instar nymphs. The aberrant individuals were isolated in separate vials and kept for subsequent development which appears rather unpredictable. Some molted and produced supernumerary adults, while others, badly deformed, were unable to shed the nymphal cuticle during metamorphosis.

The above procedure was a simple way to avoid the disadvantage of confusing normal 5th instar nymphs with those that underwent an extra molt but retained the 5th instar phenotype (Fig. 1b). It also helped to dist'guish supernumerary adults produced by 6 th stage nymphs from aberrant adults resulted from apparently normal 5th instar nymphs.

The recovered aberrant adults produced by 5 th instar nymphs and those resulted from 6th instar nymphs were tested for fertility by making single-pair matings. Abnormal females were crossed to normal males and aberrant males to normal females.

Although attention was centered on the spontaneous occurring morphogenetic juvenilization in laboratory populations, included are photographes of insect samples extracted from a study on morphogenetic juvenilization caused by juvenile hormone analogues [1- (6,7-epoxy-3-€thyl-7-methylnon-2-enyloxy) -3,4-methylene dioxybenzene] appliet to $P$. megistus 5th stage nymphs. This will form the subject of a separate paper (1). It is, nevertheless, of some interest to compare both series of observations in regard to overlapping effect groups.

The material used in both studies is completely comparable because the insects 
used were all from the same stock populations.

It seems appropriate here to mention that although both studies originated in the same laboratory, it is highly improbable that the similar effects describad below might be due to contamination. In this connection it should be emphasized that isolation of specimens wich manifested blocked development in normal populations started prior to initiation of experiments on induced morphogenetic juvenilization through application of juvenile hormone analogues. It seems also unlikely that the physical barriers between these two projects, like separate floors, etc. would permit any contamination of material.

Also, observations on control insects suggest that the juvenilizing effects observed in normal laboratory populations were not conferred by vapors of juvenile hormone mimics used throughout the experiments. Indications of such an effect has been reported by Metwally et al. (8). However, no control insects kept close to experimental insects showed any sign of deformation associated with a juvenilizing agent such as blocked development, retention of nymphal characters by adults or reduction of fecundity of insects.

\section{RESULTS}

With the exception of $P$. megistus and T. pseudomaculata there was no evidenze of spontaneous morphogenetic juvenilization in population of the remaining five species screened.

Juvenilized specimens are fairly commun in $P$. megistus. We were able to analyze $\mathbf{5 0}$ forms obtained spontaneously during two years of observations. The frequency of occurrence in $T$. pseudomaculata was much lower.

Whatever the origin of the juvenilizing effect, whether simultaneously occurring or induced by treatment with juvenile hormone analogues, the degree of juvenilization was classified according to the following scheme: supernumerary nymphs, intermediate nymphal-adult stages, badly deformed adults resulted from 5 th instar nymphs, uncoordinated development manifested by grotesque forms of adults, supernumerary adults unable to complete metamorphosis and complete supernumerary adults produced by 6 th stag 2 nymphs.

The most striking effects of derranged development in the $P$. megistus species are dep:cted in photographs of sample insects seen in Fig. 1, 2, 3 and 4.

Fig. 1a, shows a normal 5th stage nymph. Fig. 1b, and 1c, show spontaneously occurring supernumerary nymphs of variable size in which the production of imaginal characters was complety supressed. The abdominal cuticle and the wing lobs are nymphal. Fig. 1d, shows a similar degree of juvenilization caused by $\mathrm{JH}$ analogues applied to 5 th instar nymphs.

Fig. 2a, and 2b, show uncoordinated development manifested by a nymphaladult intermediate in which the initiated production of imaginal characters was impaired in the normal laboratory population. Fig. 2c, and 2d, show similar aberrations produced by topical app.ication of JH mimics to 5 th stage nymphs.

Fig. 3a, shows a normal adult. Fig. 3b, shows a malformed aduit from a 5 th instar nymph. The apex of the abdomen is rounded and wings are narrow, crumbled and light in color. Fig. $3 c$, and $3 d$ are views of faulty development manifested by grotesque forms of adults isolated in normal populations (3c), and those caused by $\mathrm{JH}$ analogues applied to 5 th stage nymphs (3d).

Fig. 4, shows badly deformed supernumerary adults, unable to shed the nymphal cuticle, and complete supernumerary adults with lateral margins of connexival band hidden under the unusual long and large wings, as compared with the normal adults seen in Fig. 3a. Insect samples shown in $4 a$, and $4 b$, were isolated in normal populations, while $4 c$, and $4 d$, ere produced by topical application of $\mathrm{JH}$ analogues to 5 th instar nymphs.

The effects of blocked development in the $T$. pseudomaculata species (previously called "maculata"; 9, 10) are seen in Fig. 5. Retention of nymphal characters is complete, as shown in Fig. 5b. A supernumerary female adult developed from a (ith stage lymph is seen in Fig. 5d.

A detailed study of the internal and external effects has not been done as yet. However, several dissection of the 
genitalia of 6 th stage nymphs and of supernumerary adults of $P$. megistus were made and enable an assessment of the effects on these organs, as in Figures 6 , $7,8,9,10$ and 11 .

Fig. $6 a$, and $6 b$, show the characters of normal male insects; 5 th stage nymph and 6 th stage adult. Fig. 6c, shows the male genitalia of a 6 th stage nymph recovered from the laboratory population. The genital capsule is completely shapless and the genital claspers are reduced to little knobs, as compared with normal 6th stage insects. The pattern of the male genitalia of a 6 th stage nymph develcped from a 5th instar treated nymph is essentially the same (Fig. 6d), and thus it may b: assumed that the juvenilizing erfects in the external male genitalia are the same in both insect samples.

Fig. 7a, b, show characters of normal female insects; 5th stage nympin and 6 th stage adult. The juven'lizing effects in external female genitalia of 6th stage nymph are manifested by a minimum differenciation of the valvulae in both insect samples, either recovered from normal population (Fig. 7c) or produced by 5 th instar nymphs treated with JH mimics (Fig. 7d).

Morpholog:cally the external genitalia in supernumerary adults showed complete development. Thus the genital claspers of male genitalia (Fig. 8) and the valvulae of female genitalia (Fig. 9, 10, 11) show approximately normal size, it should be emphasized however that while the pattern of the genital elements is fairly uniform in normal adults, pronounced variations were seen among the supernumerary adults isolated from laboratory populations and moreover; the structure for the latter (Fig. 8c, 9b, 10b, 11b) deviates from normal (Fig. 8a, 9a, 10a, 11a) to a greater extent than for individuals carrying juvenilizing effects (Fig. 8d, 9c, 10c, 11c) caused by $\mathrm{JH}$ analogues applied to 5 th instar nymphs.

No mating between supernumerary adults yielded viable eggs. Egg-laying capacity tests, by crossing supernumerary females to normal males and vice versa, revealed that these specimens were sterile, as judged by lack of viable egg production thus-far.

\section{DISCUSSION}

As Fig. 1, 2, 3 and 4 show, an excellent agreement between both groups of juvenilizing effects exists, which is rather surprising in view of the fact that one group represents morphogenetic juvenilization caused by $\mathrm{JH}$ analogues applied to 5th instar nymphs, while the other consists of spontaneous juvenilizing effects observed in laboratory populations of insects.

Although there are some differences among the structures shown in the photographes, these differences are not constant or distinctive enough to be of va.ue in separating them. Thus, it was possible to obtain comparable graded groups of forms ranging from complete juvenilization to a 6 th nymphal stage, through all degrees of intermediates up to 7 th stage adults.

The figures in both groups appear to demonstrate the same two general effects; arrested development manifested by prevention of 5 th instar nymphs from developing imaginal characters, and uncoordinated development manifested by intermediate nymphal-adult forms, adults unable to complete metamorphosis, grotesque forms of adults and supernumerary adults (7th stage).

It is evident from Fig. 6, 7, 8, 9, 10 and 11 that an identical relationship exist for the juvenilizing effects of external genitalia in both groups.

The similarity between spontaneous occurring morphogenetic juvenilization an $x$ the juvenilizing effects, induced by treatment of insects with juvenile hormone mimics, is amply confirmed by the comparative analysis of our observations with those reported by Wigglesworth on juven 1? hormone activity in Rhodnius prolixus (16) .

The complete 6 th stage $R$. pro'ixus nymph with a maximum score of juvenilization of 19 shown by Wigglesworth has a striking similarity to our 6 th stage $P$. megistus nymph shown in Fig. $1 \mathrm{~b}$, and to the supernumerary $T$. pseudomaculata nymph seen in Fig. 5b.

The question now may be asked: does evidence from the comparative analysis of the effects, observed in both groups of insect samples, support the tentative conclusion that the spontaneous juvenilizing effects, observed in the laboratory popul- 
ations of 5 th instar nymphs, truly reflect the activity of a juvenilizing hormone present in this insect?

It is difficult to get incontroversible evidence on this point because there are no published data relating factors of molting and metamorphosis in P. megistus and T. pseudomaculata, with çhich our findings can be conveniently compared. Our somewhat indirect evidence is axtracted from experimental data reported by Wigglesworth $(14,15)$.

It has been demonstrated by that author that there are two factors reguating molting and metamorphosis in krodnius prolixus. The molting hormone secreted in the brain circulates in the blood of each of tine five nymphal stages. The juvenile hormone, also called "inhibitory hormone", produced by the corpus al atum, circulates in the blood of the first four nymphal stages only. In the words of Wigglesworth, "if 5th stage nymphs in the course of molting to become adults receive inhibitory hormone from young nymphs, they may be caused to switch over to nymphal development. Such a switch over soon becomes impossible for the most specialized structures of the adult". It is believed that the latter may be responsible for the intermediate and grotesque forms of adults.

One might speculate, therefore, that the presence of the juvenile hormone in certain 5th stage insects, whatever the reasons underlying its presence, may be the actual basis for the spontaneous morphogenetic effects observed in the population.

It should be recalled in this connection that probing of engorged nymphs by unfed ones has been reported by Brumpt (2) and by Ryckman (11). By this reasoning, the 5th instar nympins, prior to being taken out of their maternal cultures, received juvenile hormone by feeding on younger nymphs. This would prevent the insect from developing imaginal characters. They might be caused to switch over to nymphal development again, or to uncoordinated development manifested by nymphal-adult intermediates and grotesque adults.

It should be emphasized however that the explanation given above is not convincing. It is a matter of conjecture whether the older insects really fed on younger nymphs and received the juvenile hor- mone which, according to Wigglesworth, influences the gene controlling the enzyme system responsible for the nymphal characteres, or whether they were juvenilized as a result, perhaps, of faulty interaction of the intracellular enzyme system, leading to some modification of the processes which "determine" the pattern of development.

The reoccurrence of such insects with identical grades of juvenilization in $P . m e-$ gistus and to a lesser extent in T. pseudomaculata, while not occurring in the other five species, screened for this kind of aberrations, is an indication that this is a genetic trait that might be inherited. If the factors responsible for the deleterious effects cannot be transmitted through the juvenilized insects by themselves because they are sterile, then they were transmitted through normal insects probably, as a recessive or a group of recessive factors.

This would not be surprising, since the "load" of hidden genetic mutations in insects is high enough to allow discovery of unusual aberrations. This helds not only for morphological traits but also for certain abnormalities involving compleated phenomenona such as gynandromorphism (3) intersexuality (7) and sex-ratio distorters (6) in insects.

It seem likely therefore, that some potential mechanism carrying factors deliterious to development is responsible for the spontaneous morphogenet:c juvenilization in vector species of Chagas disease.

Results described were sufficiently impressive to suggest that the altered phenotypes produced by the application of jlivenile hormone analogues are "phenocopies" of reactions ocurring in natural populations.

This hypotinesis gets some support from studies on induced "abnormalities" in mosquitoes. It has been shown that practically all radiation induced aberrations in Ae. egypti already exist in wild populaticns of this insect (13). It has been also suggested that "all environmentally-induced altered phenotypes have a genetic courterpart and vice versa" (12)

\section{ACKNOWLEDGEMENT}

Gratitude is expressed to Mr. A. B. Galvão for dissections of insects and to Mr. M. de Carvalho for photographic reproductions. 


\section{RESUMO}

São relatadas observações sobre a ocorrência espontâea de juvenil zação morfogenética em populações de espécies transmissoras da doença de Chagas, mantidas no laboratório.

Dois efeitos gerais foram observados: a interrupção $e$ a descoordenação do desenvolvimento. Tais efeitos são manifestados: 1) por ninfas supernumerárias ( $6^{\circ}$ estádio), 2) por estágios intermediários (ninfa-adulto), 3) por adultos sensivelmente deformados, provenientes de ninfas do $5^{\circ}$ estágis, 4) pelo desenvolv:mento descoordenado manifestado por formas adultas grotescas, 5) por adultos supernumerários incapazes de completar sua metamorfose $e$ 6) por adultos supernumerários completos, produzidos por ninfas de $6^{\circ}$ estágio.

A repetida ocorrência de insetos com idênticos graus de juvenilização, dentro de uma população, é uma indicação de que existe nestes casos, uma aberração hereditária. Os fatores responsáveis pela juvenilização morfogenética não podem ser transmitidos através de insetos juvenitizados, porque esses são estéreis, consequentemente foram transmiıidos atravśs de insetos normais, provavelmente como um recessivo ou um grupo de fatores recessivos.

A juvenilização morfogenética espontânea, observada em populações de laboratório, tem notável similaridade com os efeitos juvenilizantes induaidos pela aplicação de hormônios juvenis análogos, descritos na literatura e também obtidos no nosso laboratório num estudo em vias de publicação. Desse modo, admite-se que, não só as alterações fenotipicas que ocorrem nas populações naturais, mas também as suas "fenocópias" induzidas pela aplicação de hormônios juvenis, sejam fenômenos produzidos por reaçôes idênticas, geneticamente controladas.

\section{REFERENCES}

1. BENSON, W.; FIGUEIREDO, M.; GILB ER T, B. and PERLOWAGORASZUMLEWICZ, A. - Juvenile hormone analogues in the control of Chagas disease. I - Initial JHA screening and some activity parameters in Pastrongylus megistus (in preparation).

2. BRUMPT, E. - Importance de cannibalisme et de la coprophagie chez les Reduvides hematophages (Rhodnius, Triatoma) pour la conservation des Trypanosomes pathogens en dehors de l'hote vertabre. Bull. Soc. Path. exot. 7: 702-705, 1936.

3. CRAIG JR., B. G and HICKEY, W A. - Genetics of Insect Vectors of Disease. Amsterdam Wright/Pal. Genetics of Aedes aegypti, 67-131, 1967.

4. DAHM, K, H.; TROST, B. M. and RöLLER. H. - The iuvenile hormone - V. Synthesis of the racemic juve- nile hormone. J. Am. Chem. Soc. 89: 5292-5294, 1967.

5. DAHM, K. H.; RÖLLER, H. and TROST, B. M. -- The juvenile hormone - IV. Stereochemistry of juvenile hormone and biological activity cf some of the isomers and related Compounds. Life Sci. 7: 129-137, 1968

6. HICKEY, W. A. - Genetic distortion of sex ratios in Aedes aegypti. Proceedings of the Twelfth Intern. Congr. on Entomol., 266, 1965a.

7. LAVEN, H. - Erbliche intersexualität b i Culex pipiens. Naturwiss. 42: 517 , 1955.

8. METWALLY, M. M.; SEHNAL, F. and LANDA, $V$. - Reduction of fecundity and control of the khapra bretlo by juvenile hormone mimics. .T. Econ. Entomol., 65: 1603-1605, 1972 . 
9. PERLOWAGORA - SZUMLEWICZ, A. and CORREIA, M. V. - Induction of male sterility through manipulation of genetic mechanisms present in vector species of Chagas disease. Remarks on integrating sterile-male release with insecticidal control measures against vectors of Chagas disease ). Rev. Inst. Med. Trop. São Paulo, 14: 360-371, 1972.

10. PERLOWAGORA - SZUMLEWICZ, A.; NIGRI DA CRUZ, H. and NABUCO DE ARAUJO, J. A. - Species and stage interaction in the feeding behaviour of vectors of Chagas disease. (The importance of determinants in planning for greater efficacy and standartization of xenodiagnostic procedures). Rev. Inst. Med. Trop. São Paulo, 15: 39-150, 1973.

11. RYCKMAN, R. E. - Recent observations of cannibalism in Triatoma (Hemiptera: Reduvidae). J. Parasitol. 37: 433-434, 1951

12. STERN, C. -- Genetics of Insect Vectors of Disease. Amsterdam Wright/ Pal. Physiological Genetics, 487-504, 1967.
13. VENDEHEY, R. C. - Genetic variability in Aedes aegypti (Diptera: Culicidae), III. Plasticity in laboratory populations. Ann. Entomol. Soc. Amer. 57: 488-495, 1964.

14. WIGGLESWORTH, V. B. - Local and general factors in development of 'pattern' in Rhodnius prolixus (Hemiptera). J . Exp. Biol. 17: 180-200, 1940

15. WIGGLESWORTH, V. B. - The determination of characters at metamorphosis in Rhodnius prolixus (Hemiptera). J. Exp. Biol. 17: 201-221, 1940 .

16. WIGGLESWORTH, V. B. - Chemical structure and juvenile hormone activity: Comparative tests on Rhodnius prolixus. J. Insect Physiol. 15: 73-94, 1969 .

17. WILLIAMS, C. M. - The iuvenile hormone of insects. Nature, London. 178: 212-213, 1956 .

18. WILLIAMS, C. M. - and LAW, J. H. - The juvenile hormone - IV. Its extraction, assay and purification. $\mathbf{J}$. Insect Physiol, 11: 569-580, 1965. 

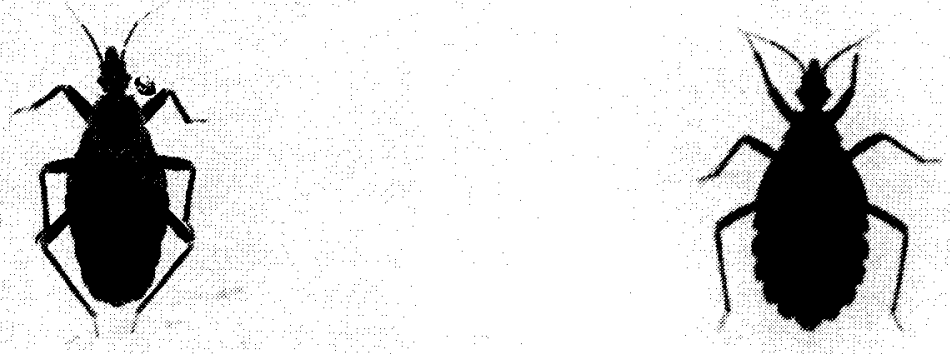

a
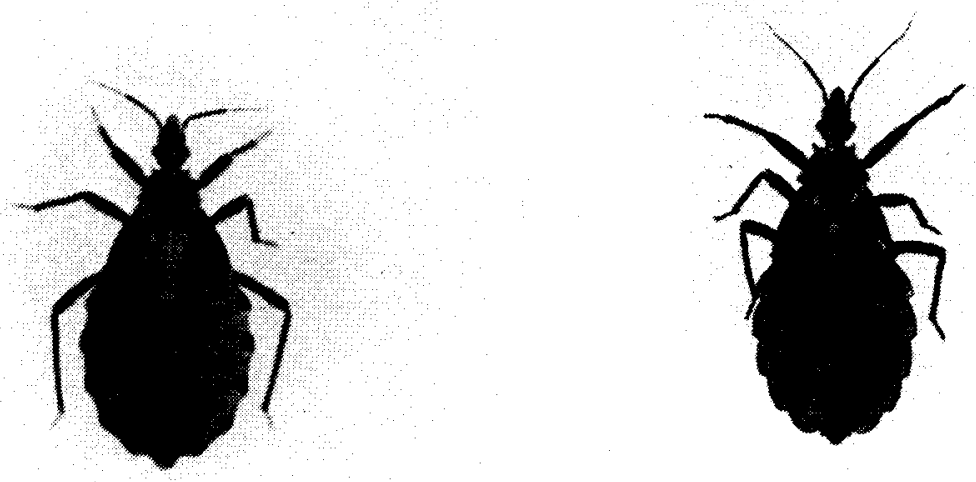

C

Ftg. 1 - P. megistus: a, - normal 5th stage nymph; b, c, - extra nymphal stages from laboratory population; d, - extra nymphal stage produced by $\mathrm{JH}$ analogue. 

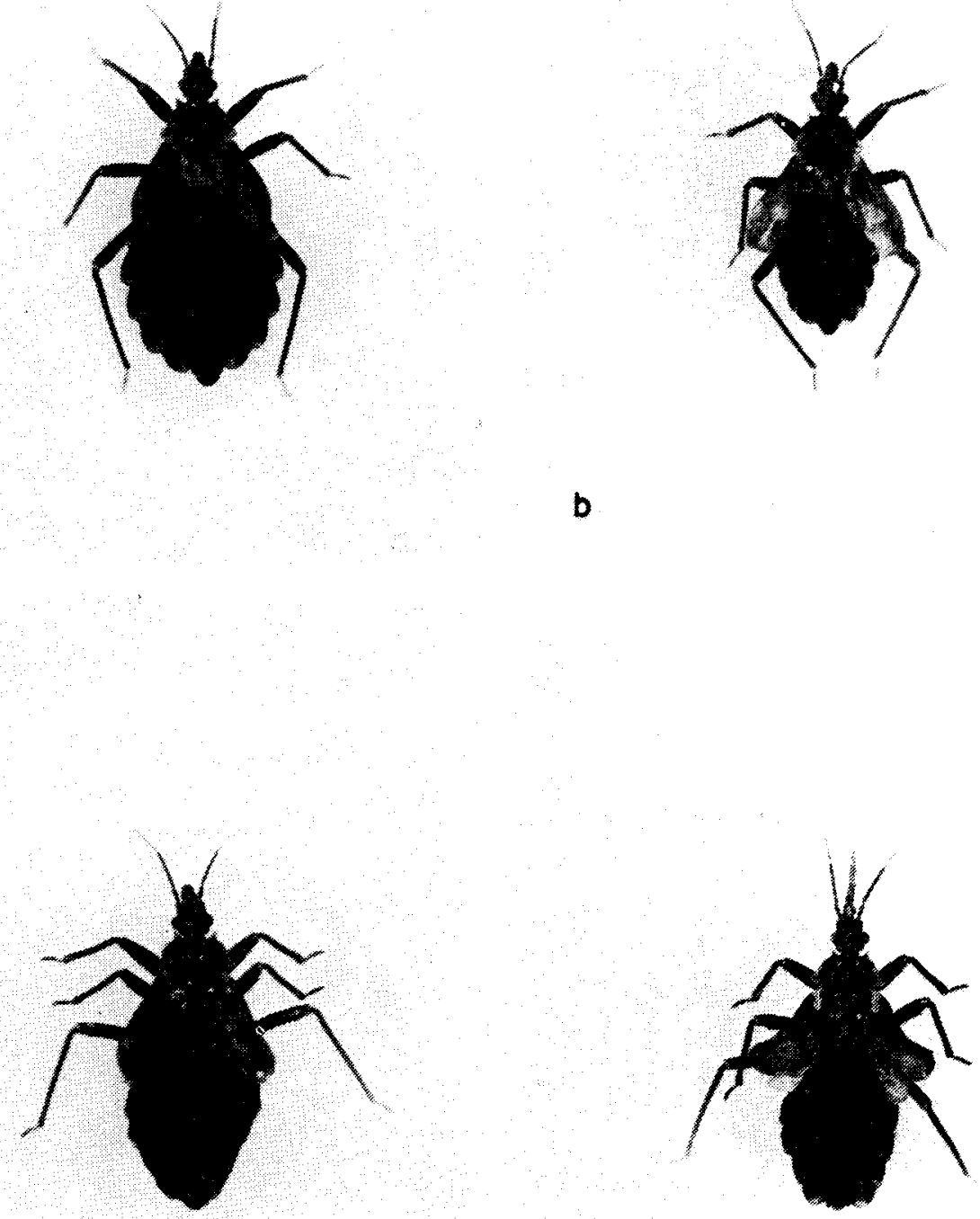

C

Fig. 2 - P. megistus: a, b, - intermedlate forms from laboratory population; c. d. intermediate forms produced by $\mathrm{JH}$ analogue. 

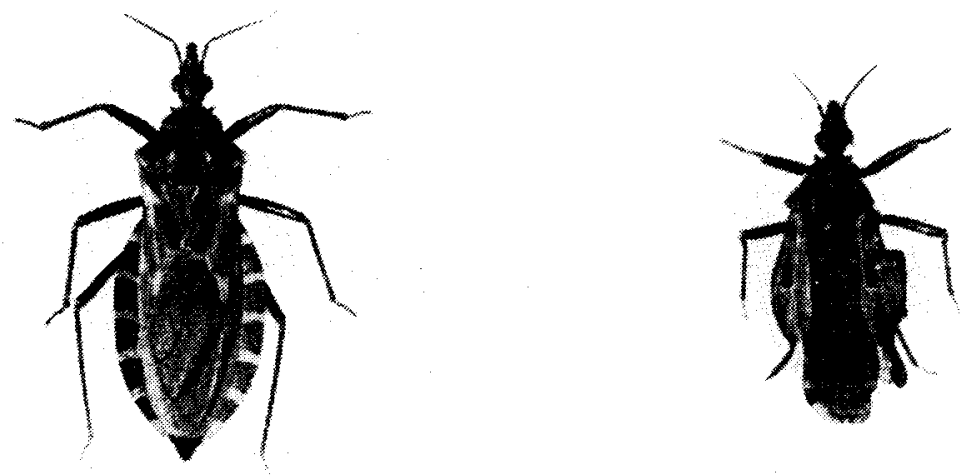

$a$

b
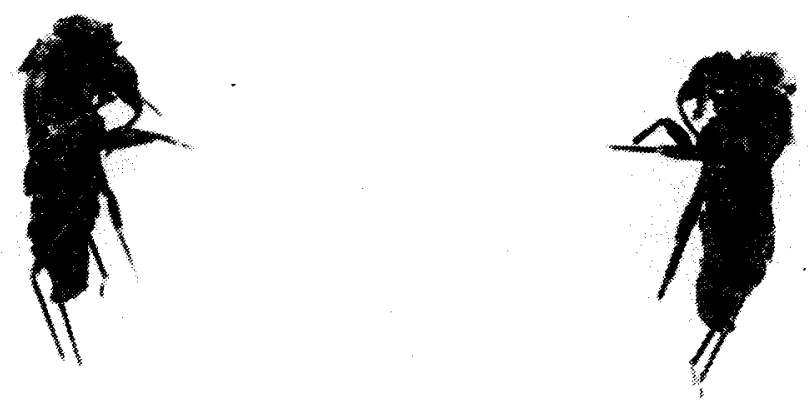

c

d

Fig. 3 - P. megistus: a. - normal adult; b, c, - aberrant adults from laboratory population: d, - grotesque adult produced by JH analogue. 


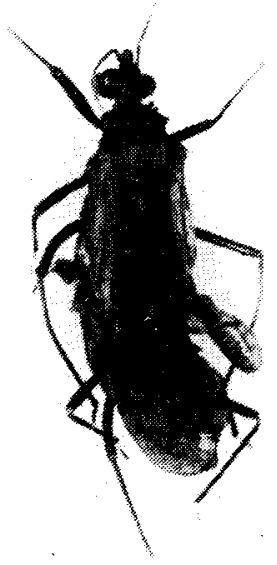

o

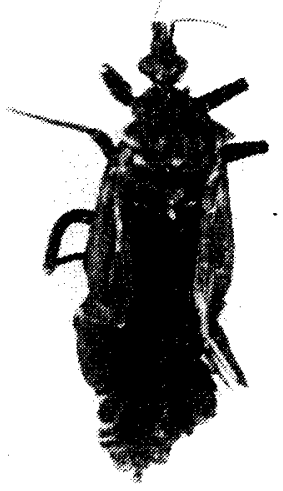

c

Fig. $4-P$. megistus: $\mathrm{a}, \mathrm{b},-$ incomplete and complete supernumerary adults from laboratory population; $c, d,-$ incomplete and complete supernumerary adults
produced by JH analogue. b

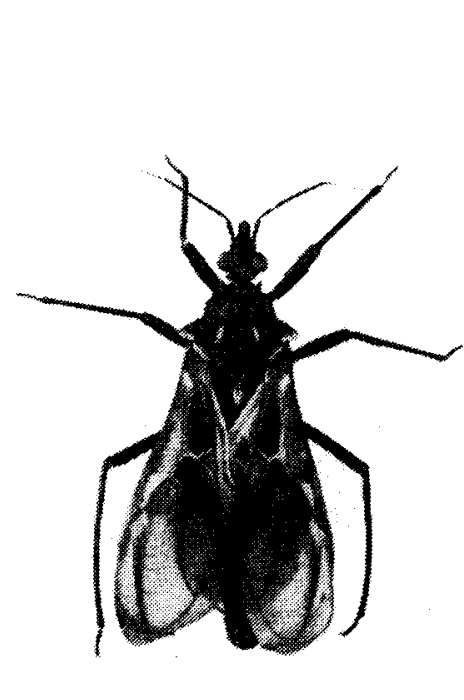

d

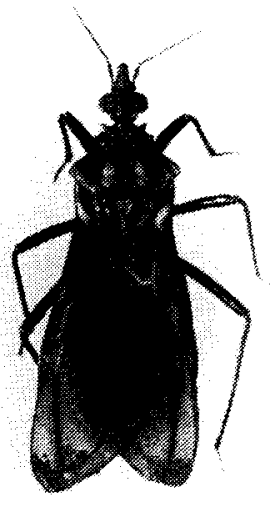



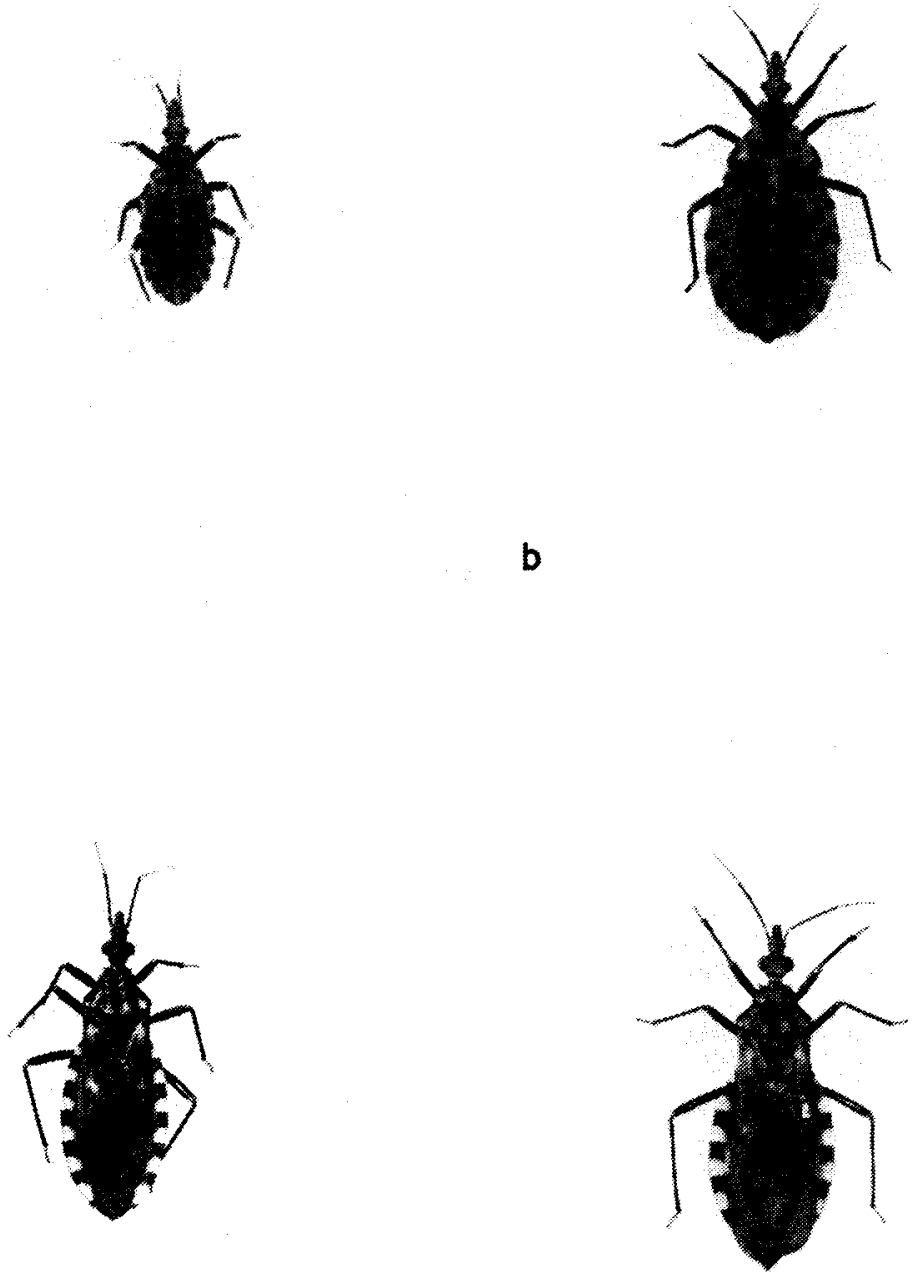

C

Fig. $5-T$. pseudomaculata: a, - normal 5 th stage nymph; b, - extra nymphal stage; c, - normal female adult; $d$, - complete extranumerary female adult. 


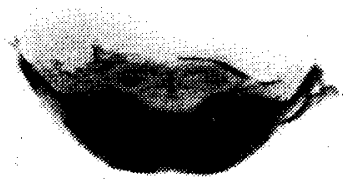

a

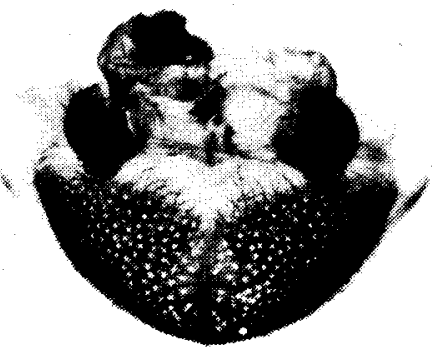

c

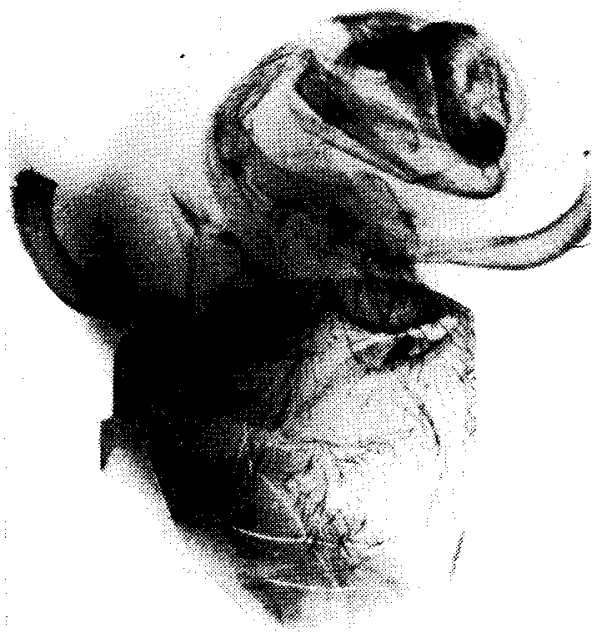

b

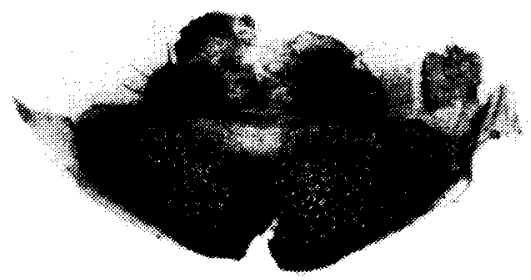

d

Fig. 6 - External male genitalia of $P$. megistus (x 20) : a, - normal 5 th stage nymph; b, - normal adult; c, - extra nymphal stage from laboratory population: d, - extra nymphal stage produced by JH analogue. 


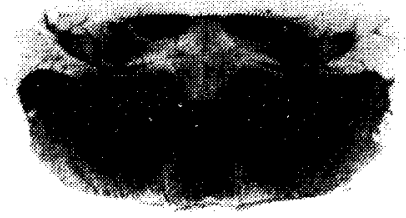

a

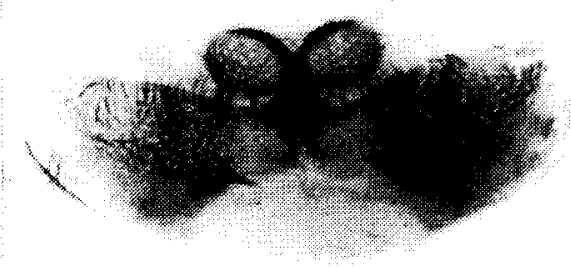

C

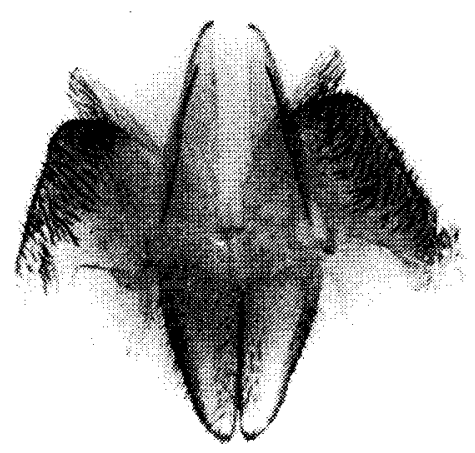

b

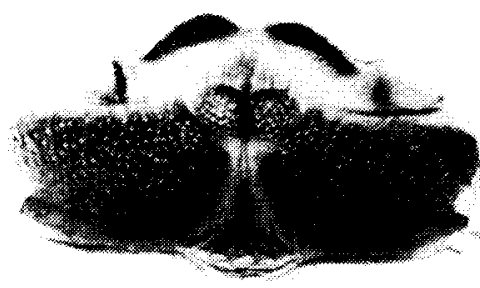

c

Fig. 7 - External female genitalia of $P$. megistus (x 13): a, - normal 5 th stage nymph: b, - normal adult; c, - extra nymphal stage from laboratory population; $\mathrm{d}$, - extra nymphal stage produced by $\mathrm{JH}$ analogue. 


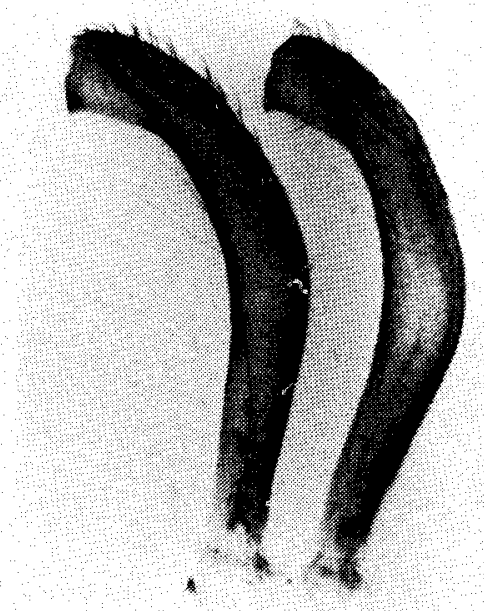

a

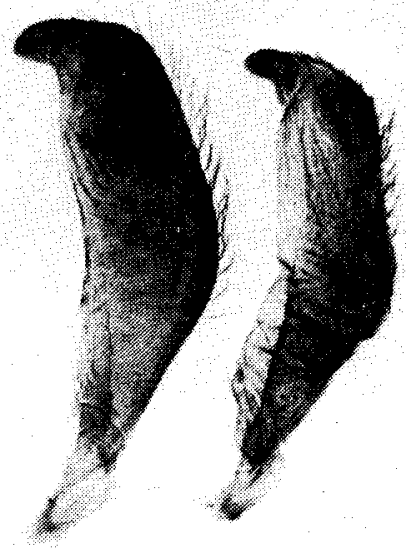

c

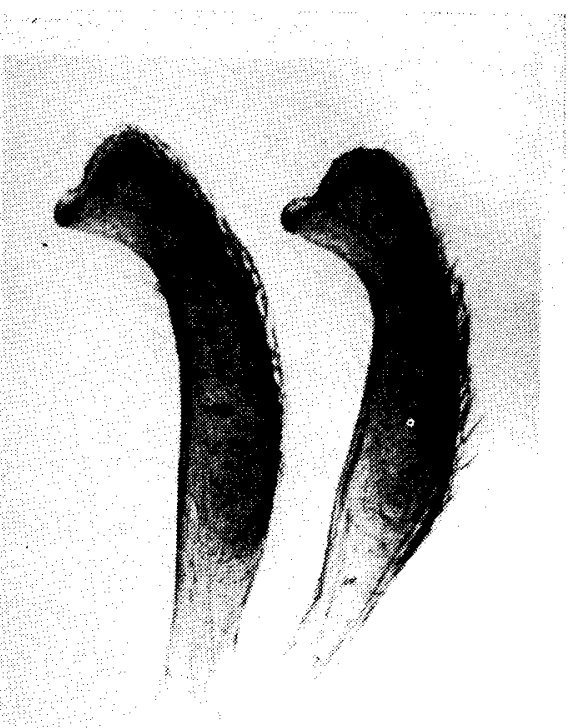

b

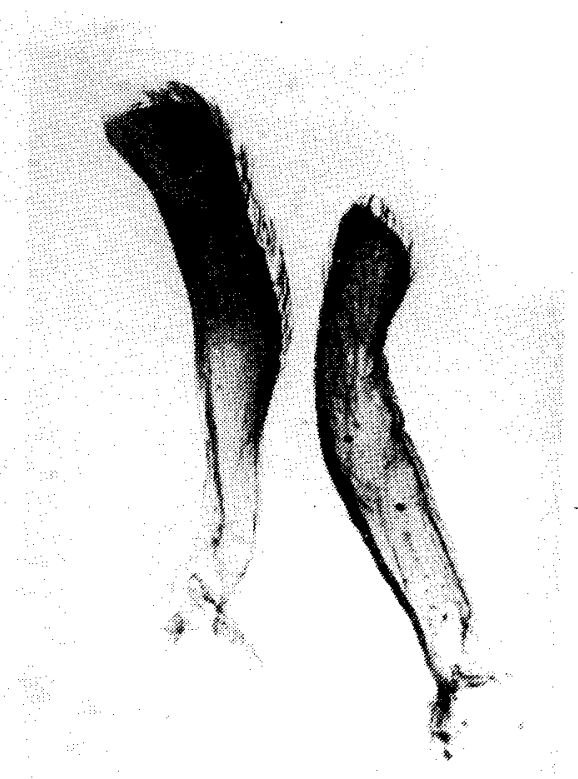

d

Fig. 8 - Male genital claspers of $P$. megistus: a, - normal adult; b, c, - supernumerary adults from laboratory population; d, - supernumerary adult produced by $\mathrm{JH}$ analogue. 

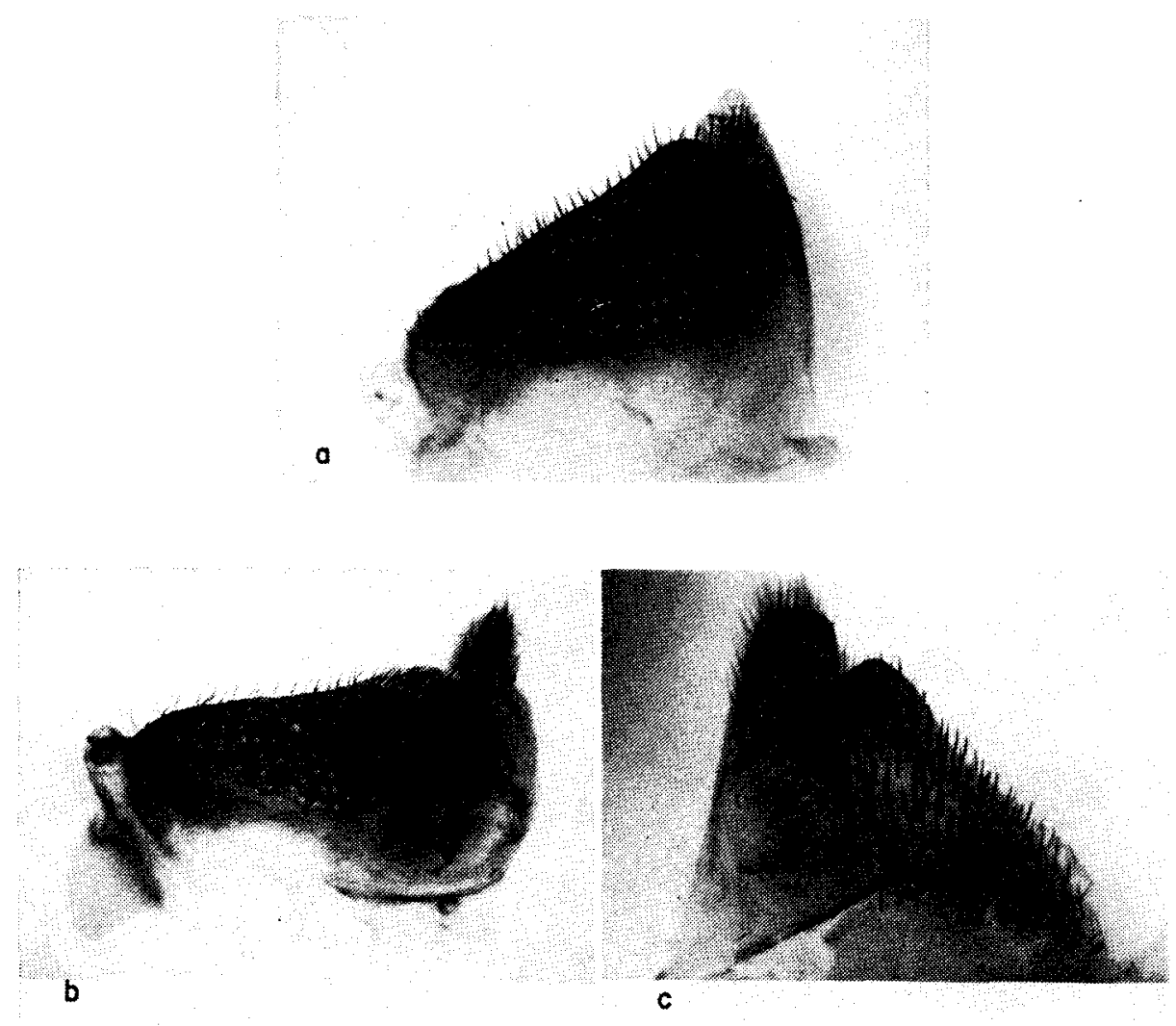

Fig. 9 - Gonocoxae and gonapophysis of $8^{\circ}$ sternite in female $P$. megistus: a, - normal acult; b, - supernumerary adult from laboratcry population; c, - supernumerary adult produced by JH analogue. 


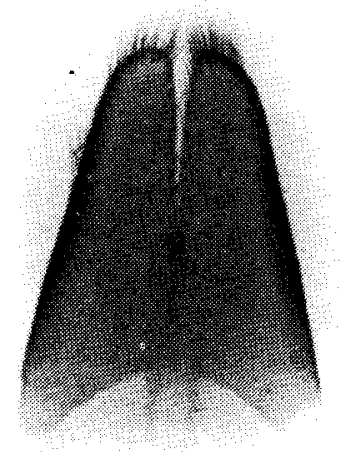

a

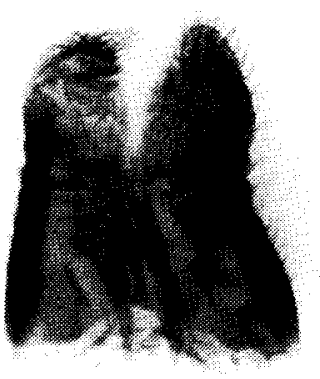

b

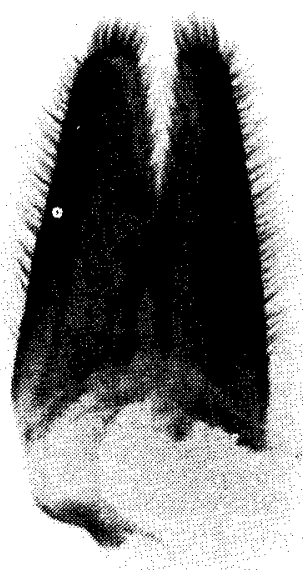

C

Fig. 10 - Gonocoxae of 9 sternite in female $P$. megistus: a, - normal adult; b, surernumerary adult frcm laboratory population; c, - supernumerary adult produced by JH analogue. 

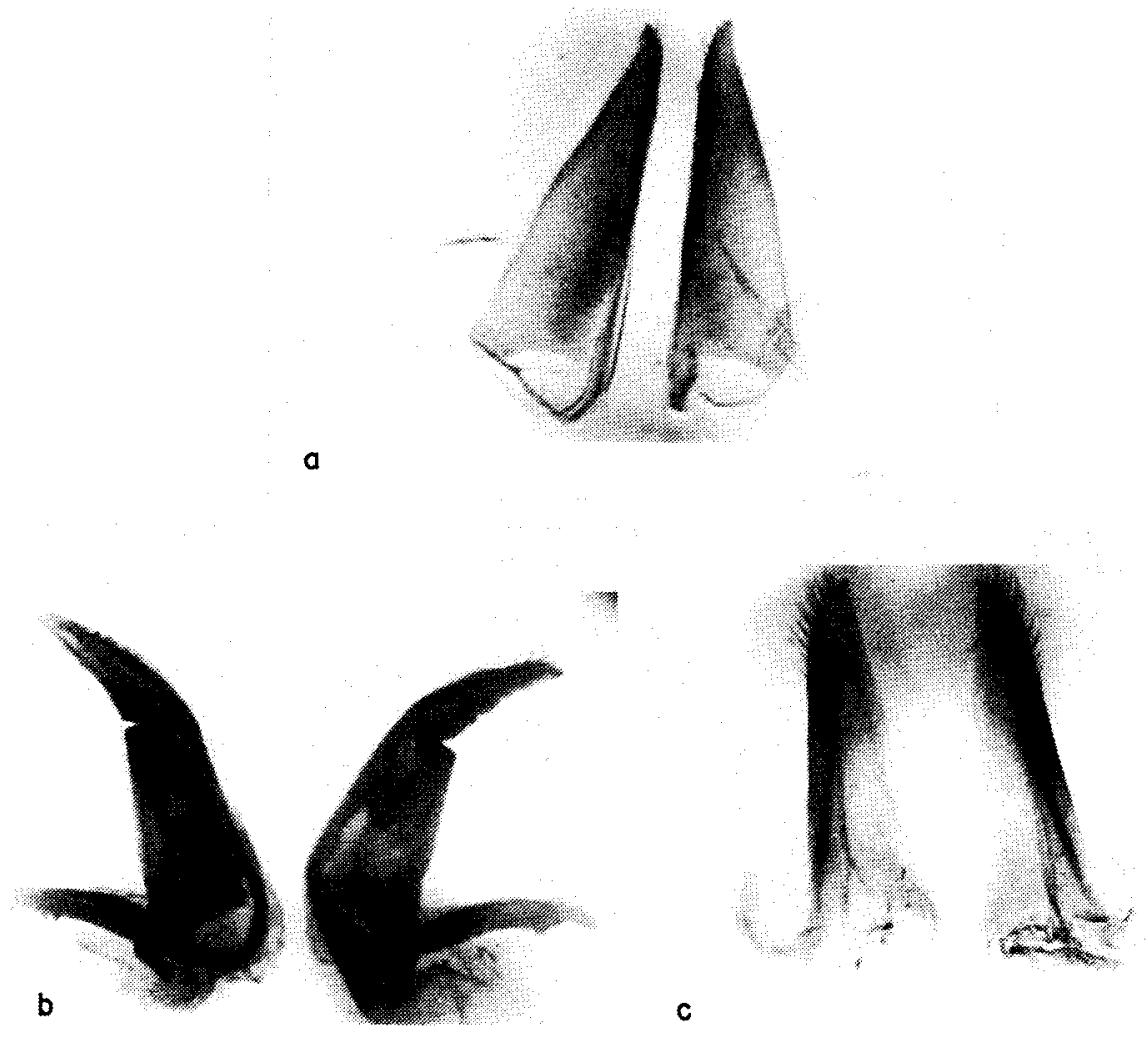

Fig. 11 - Gonapophysis of $9^{\circ}$ sternite in female $P$. megistus: a, - normal adult; $b,-$ supernumeraré adult from laboratory population; c, - supernumerary adult produced by $\mathrm{JH}$ anklogue. 